\title{
LOCAL EFFECTS OF THE SPHINGOSINE 1-PHOSPHATE ON PROSTAGLANDIN F2ALPHA-INDUCED LUTEOLYSIS IN THE PREGNANT RAT
}

\author{
Fatima Hernandez ${ }^{1}$, Marina C. Peluffo ${ }^{2,{ }^{*}}$, Diana Bas ${ }^{1}$, Richard L. Stouffer ${ }^{2}$, and Marta \\ Tesone ${ }^{1,3}$ \\ ${ }^{3}$ Departamento de Química Biológica, Facultad de Ciencias Exactas y Naturales, Universidad de \\ Buenos Aires, Buenos Aires, Argentina
}

\begin{abstract}
Since the regression of the corpus luteum (CL) occurs via a tightly controlled apoptotic process, studies were designed to determine if local administration of the antiapoptotic agent sphingosine-1-phosphate (S1P) effectively blocks the luteolytic action of PGF-2alpha (PGF-2a). On day 19 of pregnancy, $2 \mathrm{~h}$ before systemic PGF-2a administration, rats were injected intrabursa with either S1P or vehicle (control). The activity of four caspases, which contribute to the initial (caspase-2, -8 and -9) and final (caspase-3) events in apoptosis was measured in pooled CL from 4 individual ovaries at $0 \mathrm{~h}$ and $4 \mathrm{~h}$ after PGF-2a injection. The expression of the phosphorylated form of AKT (pAKT) and TNF- $a$ was analyzed by ELISA. In addition, cell death was evaluated by electronic microscopy (EM) in CL 4 and $36 \mathrm{~h}$ after PGF-2a injection. The activity of caspase- $2,-3$ and -8 was significantly greater by 4 h after PGF- $2 a$ but not caspase- 9 activity. In contrast, expression of pAKT and TNF-a decreased significantly. Administration of S1P suppressed $(\mathrm{p}<0.05)$ these effects, decreasing caspase activities and increasing pAKT and TNF- $a$ expression. The administration of S1P also significantly decreased the percentage of luteal apoptotic cells induced by PGF-2a. PGF-2 $a$ treatment increased the prevalence of luteal cells with advanced signs of apoptosis (i.e. multiple nuclear fragments, chromatin condensation or apoptotic bodies). S1P treatment suppressed these changes and increased the blood vessel density. These results suggest that S1P blocks the luteolytic effect of the PGF- $2 a$ by decreasing caspase-2, -3 and -8 activities and increasing AKT phosphorylation and TNF- $a$ expression.
\end{abstract}

\section{Keywords}

Luteolysis; apoptosis; corpus luteum; PGF-2a; Sphingosine 1-P

Correspondence: Marta Tesone, Instituto de Biología y Medicina Experimental, Obligado 2490, 1428 Buenos Aires, Argentina., FAX 540114786 2564; mtesone@dna.uba.ar.

${ }^{1}$ Current address: Instituto de Biología y Medicina Experimental (IBYME)-CONICET-

${ }^{2}$ Current address: Division of Reproductive Sciences, Oregon National Primate Research Center, Oregon Health \& Science

University, 505 NW 185th Avenue, Beaverton, OR 97006

* $\mathrm{HF}$ and PMC contributed equally to this work 


\section{Introduction}

The corpus luteum (CL) is a transient endocrine gland that forms from the remaining wall of the ovarian follicle after ovulation. The formation and regression of the CL requires rapid remodeling, growth, differentiation and death of its heterogeneous population of cells. This gland consists of not only steroidogenic cells (large and small), but also vascular endothelial cells, fibroblasts, smooth muscle cells and immune cells (Channing, 1969a; Channing, 1969b). After ovulation, vascular elements in the theca layer of the antral follicle invade the avascular granulosa layer to establish an extensive capillary network that nourishes the developing CL (Koos R.D., 1993; Hazzard and Stouffer, R. L., 2000). The CL's main function is to secrete the steroid hormone progesterone $(\mathrm{P})$, which is essential for implantation of the blastocyst and maintenance of pregnancy (Bowen-Shauver and Gibori, G., 2004; Stocco et al., 2007; Stouffer, 2004). However, if pregnancy does not occurs, at the end of each ovarian cycle or when it is not required for maintenance of pregnancy, the CL ceases to produce progesterone and regresses in a process called luteolysis. This process occurs in two phases. The first one is known as functional luteolysis, which consists of the loss of its ability to produce P. The second and following phase termed structural luteolysis consists of the morphological regression/involution of the CL. Moreover, the integrity and function of the luteal vasculature declines during regression of the CL near the end of the cycle (Hazzard and Stouffer, R. L., 2000).

Prostaglandin F-2a (PGF-2a) has been established as the main luteolytic factor in several species, including rodents and domestic animals (Pharriss, 1971; Pharriss et al., 1972; Pharriss and Wyngarden, L. J., 1969). The actions of PGF-2a, include reduction of ovarian blood flow, uncoupling of the LH receptor from adenylate cyclase, reduction of steroidogenic enzyme activity and progesterone production, decrease of LH receptor concentration, changes in membrane fluidity, changes in luteal cell population, and increase in lysosomal enzyme activity (Niswender GD and Nett TM, 1994; Hansel and Blair, R. M., 1996; Milvae et al., 1996).

Apoptosis or programmed cell death has been related with luteal regression in many species, (Bacci et al., 1996; Bowen et al., 1996; Gaytan et al., 1998; Goodman et al., 1998; Guo et al., 1998; Hasumoto et al., 1997; Telleria et al., 2001; Yadav et al., 2005), but the precise cellular events associated with this mechanism are not well established. Signaling for apoptosis occurs through multiple independent pathways that are initiated either from triggering events within (intrinsic pathway) or from outside the cell (extrinsic pathway). All these pathways converge in a common machinery of cell destruction that usually involves the effector caspases, e.g., caspase-3. Members of the caspase family are cysteine aspartic acid-specific proteases that play a key role in the apoptosis, and their activation is a critical event in this process (Alnemri et al., 1996; Guo et al., 2002; Martin and Green, D. R., 1995; Nicholson, 1999). These proteases regulate the selective destruction of key proteins of the cell, such as PARP [poly (ADP-ribose) polymerase], lamin, fodrin (Chinnaiyan and Dixit, V. M., 1996; Cryns and Yuan, J., 1998; Thornberry and Lazebnik, Y., 1998). Several caspases have been identified within the CL in different species (Krajewska et al., 1997; Boone and Tsang, B. K., 1998; Rueda et al., 1999; Khan et al., 2000; Abdo et al., 2001; Peluffo et al., 2005; Peluffo et al., 2006; Yadav et al., 2005; Peluffo et al., 2007). Moreover, 
there is evidence that PGF-2a plays an important role in regulating the activity of several members of the caspase family in the rat CL(Yadav et al., 2005; Peluffo et al., 2007).

The sphingolipid metabolites ceramide, sphingosine and the sphingolipid metabolite, sphingosine 1-phosphate (S1P) play and important role in the regulation of cellular fate. Ceramide and sphingosine usually inhibit proliferation and promote apoptosis, while the further metabolite S1P has been implicated in the protection from apoptosis and stimulation of angiogenesis (Cuvillier et al., 1996; Spiegel and Milstien, S., 2003a; Oyama et al., 2008). It has been described that ceramide and acid sphingomyelinase (the enzyme responsible for the conversion of sphingomyelin to ceramide) are potent inducers of apoptosis in luteinized granulosa cell (Pru et al., 2002). Concerning S1P, this is an important signaling molecule in ovarian cancer that regulates both growth and metastatic potentials of ovarian cancer cells (Xu et al., 1995; Xu et al., 1995; Xu et al., 1998; Hong et al., 1999; Xu et al., 2001; Schwartz et al., 2001). In rodents, intrabursa ovarian injection of S1P two hours before ionizing radiation prevents the massive follicular/oocyte destruction caused by irradiation, presumably by a S1P -mediated apoptosis inhibition (Morita et al., 2000; Hancke et al., 2007).

We hypothesized that, if apoptosis plays a key role in PGF-2a-induced luteolysis in rodents, then S1P would prevent PGF-2a induced effects and rescue the CL from regression. Therefore, studies were designed to analyze the activity of three initiator caspases (caspases-2, -8 and -9) and the main effector caspase-3, as well as morphological and ultrastructural features of apoptosis, during PGF-2a-induced luteolysis and after local administration of the antiapoptotic agent S1P during PGF-2a treatment. We also examined the expression and phosphorylation of the kinase AKT, which is a key intracellular mediator of signals for cell survival, proliferation, and angiogenesis. Also, the expression of tumor necrosis factor- alpha (TNF-a), a key cytokine involved in both death and cell survival, was analyzed.

\section{Results}

\section{Indices of luteal structure-function after PGF-2 $a$ and S1P/PGF-2 $a$ treatments: corpus luteum ultrastructural morphology, PECAM-1 expression and progesterone luteal levels}

Ultrastructural analysis of the CL by EM (Figure 1), revealed that most of the luteal cells at day 19 of pregnancy exhibited a healthy nucleus as well as, many lipid drops; but very few indices of apoptotic and non-apoptotic cell death (Figure 1, Panel A, B). As expected, PGF-2a treatment increased luteal cells with signs of advanced apoptosis (i.e. multiple nuclear fragments, chromatin condensation or apoptotic bodies) by $36 \mathrm{~h}$ post-injection (Figure 1, Panel C, D). Administration of S1P 2 hours prior PGF-2a suppressed these changes and most of the cells presented healthy nucleus (Figure 1, Panel E, F). And interestingly, an increase in blood vessel density was also observed in this group. None of these changes were observed after $4 \mathrm{~h}$ of treatments (data not shown).

To further examine blood vessels in the CL, luteal sections from all groups were stained for the vascular endothelial cell marker PECAM-1 (Figure 2) (DeLisser et al., 1993). Immunohistochemistry analysis revealed that PECAM-1 was expressed in the CL at day 19 
of pregnancy (Figure 2, Panel B), and that treatment with PGF-2a appeared to decrease its expression (Figure 2, Panel C, D). Nonetheless, treatment with S1P prevented this decrease, and in fact, stimulated the PECAM-1 expression in the CL (Figure 2, Panel E, F). Progesterone content was measured in isolated CLs in all the groups (C0h, PG4h, PG+S4h, PG36h \& PG+S36h) to examine whether S1P could revert the expected decrease in progesterone levels after PGF-2 $a$ treatment (Figure 3). Administration of PGF-2 $a$ to pregnant rats at day 19 of gestation rapidly (4h) decreased luteal progesterone content $(\mathrm{p}<0.05)$ and levels remained low at $36 \mathrm{~h}$. Notably, S1P failed to prevent this effect of the PGF-2 $a$ by 4 h post-injection. But, by 36 hours after PGF- $2 a$ administration S1P treatment maintained the luteal progesterone content at levels observed in the control group $(\mathrm{COh})$. Accordingly, we found a significant increase in progesterone content in the $\mathrm{PG}+\mathrm{S} 36 \mathrm{~h}$ group in comparison to the PGF-2a groups (PG4h \& PG36h) as well as, to the PG+S4h group $(\mathrm{p}<0.05)$.

\section{Local effects of S1P on caspase (-2, $-8,-9$ and -3$)$ activity and luteal cell death during Prostaglandin F $2 a$-induced luteolysis in the rat}

Following PGF-2a administration at day 19 of pregnancy, the activity of the initiator caspases (-2, and -8), as well as the main effector caspase-3, significantly increased by 4 hours ( $p<0.05$; Figure 4, Panel A, C, B, respectively). Intrabursa administration of the S1P 2 hours prior PGF-2a injection prevented $(\mathrm{p}<0.05)$ at least in part this increase. However, there were no significantly changes for the activity of the initiator caspase- 9 between groups (Figure 4, Panel D). Although treatment with PGF-2a tended to increase caspase-9 activity, this effect was not statistically significant $(\mathrm{p}>0.05)$.

TUNEL analysis (Figure 5, Panel A) showed the presence of few cells with nuclear DNA fragmentation in the rat CL at day 19 of pregnancy. By 4 hours after PGF-2a administration, the number of cells showing advanced signs of apoptosis significantly increased $(\mathrm{p}<0.05)$.

As expected, administration of the antiapoptotic agent S1P prevented this effect and significantly decreased $(\mathrm{p}<0.05)$ the percentage of apoptotic cells in the rat CL induced by PGF-2 $a$ administration (Figure 5, Panel B). Cells exhibiting TUNEL staining were expressed as the percentage of apoptotic cells in each group. Staining was not found in the negative control without the TdT enzyme (Panel A), nor in the surrounding stroma (not shown).

\section{Stimulation of protein levels of TNF-a and the phosphorylated form of AKT by S1P on a Prostaglandin F2a-induced luteolysis model}

Administration of PGF-2 $a$ almost abolished the luteal expression of TNF- $a$ by 4 hours post injection (Figure 6, Panel A). In contrast, S1P treatment prevented $(\mathrm{p}<0.05)$ the effects of PGF-2 $a$ on TNF- $a$ levels. At day 19 of pregnancy, PGF-2a treatment modestly but significantly decreased $(\mathrm{p}<0.05)$ the levels of the phosphorylated form of AKT (Figure 6, Panel B) in the CL. However, administration of S1P 2 hours prior PGF- $2 a$ injection prevented this decrease and increased levels to above those in controls $(\mathrm{p}<0.05, \mathrm{C} 4 \mathrm{~h})$.

Western blot of pAKT and AKT was used to determine whether protein expression of AKT was not modified by PGF-2a or S1P. Densitometric quantification of pAKT/AKT shows 
similar results to those obtained using ELISA (data not shown), suggesting that the increase in the phosphorylated form of AKT is related with changes in the phosphorylation/ desphosphorylation rather than protein synthesis/turnover.

\section{Discussion}

The caspase measurements in this study showed that the activity of caspase- $2,-3$ and -8 was significantly greater by $4 \mathrm{~h}$ after PGF- $2 a$ administration. However caspase- 9 activity was unchanged, indicating that caspase-9 may be not essential or even necessary for prostaglandin F2alpha-induced luteolysis in the pregnant rat. In fact, these results are in accordance with results obtained from Yadav et al (Yadav et al., 2005). Although caspase-9 activity was not influenced by PGF-2 $a$ in the rat CL, the intrinsic apoptotic pathway cannot be discarded, as caspase- 2 can link both the extrinsic death receptor and the intrinsic mitochondrial pathways through the cleavage of a member of the Bcl-2 family, Bid (Guo et al., 2002). Besides, there it could also be due of time, dose or lack of pulsatile secretion of this hormone. Therefore, physiologic luteal regression may involve the cooperation of both extrinsic and intrinsic apoptotic pathways. Several studies demonstrate the presence of the extrinsic pathway in the luteal cells (Abdo et al., 2003; Carambula et al., 2003; Yadav et al., 2005; Kuranaga et al., 1999), although there are also data supporting the involvement of the intrinsic mitochondrial pathway in luteal cell death (Goyeneche et al., 2006; Papadopoulos et al., 1999).

Interestingly, local treatment with S1P 2 hours prior PGF- $2 a$ could revert this increase in caspase-2, -3 and -8 induced by PGF- $2 a$ at least in part, tending to protect the CL from the caspase cascade. In agreement with caspase activities, the percentage of apoptotic cells significantly increased by 4 hours after PGF- $2 a$ administration. And, the administration of S1P significantly decreased the percentage of apoptotic cells in the rat CL induced by PGF-2 $a$ administration. S1P is a bioactive sphingolipid metabolite formed by the phosphorylation of sphingosine by sphingosine kinase. It is implicated in many biological processes and it is well known as an antiapoptotic agent (Spiegel and Milstien, S., 2000; Payne et al., 2002; Alvarez et al., 2007). Besides, ceramide can be metabolized via ceramidase to S1P and in some cell types the dynamic balance of S1P and ceramide acts as a 'cellular rheostat' that determines the fate of the cell (Payne et al., 2002). S1P was shown to inhibit the activation of effector caspases (eg. caspase-3, -6, and -7) in human leukemia cells, by counteracting the release of mitochondrial proteins, cytochrome $\mathrm{c}$ and Smac/ DIABLO induced by a variety of different factors (e.g. Fas monoclonal antibody, serum deprivation, or exogenous ceramides) (Cuvillier and Levade, T., 2001). Intrabursa ovarian injection of S1P two hours before ionizing radiation prevents the massive follicular/oocyte destruction caused by irradiation, presumably by a S1P -mediated apoptosis inhibition (Morita et al., 2000). However, this is the first study that describes the effect of S1P on apoptosis and different caspase activities in the corpus luteum. Experiments are in progress in our laboratory using sphingosine kinase inhibitors to demonstrate if sphingosine plays a role on the physiological luteolytic process associated with late pregnancy.

Surprisingly, PGF-2a treatment at day 19 of pregnancy almost abolished the luteal expression of TNF-a by 4 hours post injection. S1P reversed its expression in the CL, 
suggesting that S1P pre-treatment is able to prevent prostaglandin effect. These results differ from the results obtained from Henkes et al 2008, where PGF-2a treatment causes a significant increase in ovarian TNF-a during CL regression in pseudopregnant mice (Henkes et al., 2008). Differences may be due on the different experimental models or PGF-2 $a$ protocols, since there are reports that suggest TNF- $a$ can initiate luteotropic or luteolytic effects depending on the stage of the cycle, species or local milieu in the CL (Davis and Rueda, B. R., 2002). It is important to consider that the binding of TNF-a to its receptor can trigger the survival of the cells through the activation of the nuclear factorkappa B (NF- кB) (Wang et al., 1996; Beg and Baltimore, D., 1996; Wu et al., 1996). The activation of NF- $\kappa$ B by TNF- $\alpha$ and the expression of adhesion molecules requires Sphingosine Kinase (SphK) and these events are crucial for the protection of endothelial cells against the apoptotic effects of TNF-a (Xia et al., 1998; Xia et al., 1999). S1P can stimulate several transcription factors that have been implicated in cell growth regulation and protection against apoptosis, including NF- $\mathrm{B}$ (May and Ghosh, S., 1999). Also, there may be a cross-talk between TNF- $a$ and S1P receptors (Alvarez et al., 2007). Accordingly, in our model of PGF-2a-induced luteolysis in pregnant rats, S1P may be stimulating its own synthesis and survival of the cell by stimulation the expression of TNF- $a$, and possibly the activation of NF- $\kappa$ B. TNF- $a$ is primarily expressed in the monocytes or macrophages, but it is also found in the endothelial cells of the CL (Zhao et al., 1998; Petroff et al., 1999). Interestingly, immune cells, as well as cytokines, play a role in regulating luteal function in rats, mice, cows and women (Brannstrom and Friden, B., 1997; Friedman et al., 2000; Terranova and Rice, V. M., 1997).

It is well known that PI3K/AKT is a pathway involved in cell survival and proliferation. PI3K/AKT signaling was shown to play a key role in regulating cell cycle progression by promoting G1-S phase transition. AKT can block cell-cycle inhibitors and stabilizes proteins that promote cell-cycle progression (Gao et al., 2003; Gao et al., 2004; Engelman et al., 2006; Jiang and Liu, L. Z., 2008). In this study, we investigated whether PGF-2a may exert its luteolytic role and promote apoptosis by regulating this pathway. Treatment with PGF-2a at day 19 of pregnancy significantly decreased the levels of the phosphorylated form of AKT at Ser 473. In addition, administration of S1P 2 hours prior PGF-2a injection reverted this effect. These results suggest that PI3K/AKT signaling pathway is inhibited by PGF- $2 a$ in CL from pregnant rats and the antiapoptotic agent S1P was able to reverted this effect. Accordingly, in other system it was demonstrated that exogenous administration of S1P was found to activate AKT and partially rescued the cells from the apoptosis (Osawa et al., 2001).

We further investigated whether ultrastructural CL parameters were altered by PGF-2 $a$ or PGF-2a /S1P treatments. Analysis of the CL by EM, revealed that most of the luteal cells at day 19 of pregnancy presented healthy nucleus as well as, many lipid drops; but very few indices of apoptotic cell death. As expected, PGF-2 $a$ increased luteal cells with advanced signs of apoptosis (i.e. containing multiple nuclear fragments, chromatin condensation or apoptotic bodies) by $36 \mathrm{~h}$ post-injection. S1P treatment, whereas suppressed these changes and most of the cells presented healthy nucleus. Interestingly, an increase in blood vessel density was also observed in this group. It is important to note that in addition to its antiapoptotic effects, S1P is also an angiogenic factor comparable to basic fibroblast growth 
factor (FGF-2) and VEGF in promoting vessel growth, and synergizes with these factors to promote development of vascular network in vivo (Igarashi et al., 2003; Spiegel and Milstien, S., 2003b; Balthasar et al., 2008; Ferrara et al., 2006). In previous studies (Abramovich et al., 2006; Parborell et al., 2008) we have demonstrated that angiogenic factors have an important role in the processes of follicular selection, dominance and atresia mediated by apoptosis. The present results show that PECAM-1, a specific protein for microvascular endothelial cells, was expressed in the CL at day 19 of pregnancy, and that treatment with PGF- $2 a$ vastly decreased its expression. Nonetheless, treatment with S1P reverted this decrease, and in fact, stimulated the PECAM-1 expression in the CL, suggesting that endothelial cell survival may be involved in the antiapoptotic effect of S1P. Furthermore, S1P receptors are expressed in vascular endothelial cells (Chae et al., 2004; Sanchez et al., 2007; Sanchez and Hla, T., 2004; Maines et al., 2006). Therefore, the blockage of luteolysis by S1P may be due to the stimulation of angiogenesis, an inhibition of luteal apoptosis, or a combination of both. Further information is needed to elucidate the relevance of the changes observed in the vasculature after S1P treatment.

Luteal progesterone content measurements reflected the ultrastructural changes observed by EM, since administration of PGF-2a to pregnant rats rapidly decreased progesterone content and by 36 hours after PGF-2 $a$ administration S1P treatment could recover the luteal progesterone content. Unexpectedly, S1P failed to prevent this effect of the PGF-2a by $4 \mathrm{~h}$ post-injection. It was suggested that the reduced ability of luteal cells to produce progesterone can induce cell death (Liszewska et al., 2005). However, in our experimental model one could hypothesize that functional luteolysis occurs by 4 hours after PGF-2a administration involving changes in the activity of steroidogenic enzymes able to be reverted after a prolonged exposure to S1P.

In summary, the results reported here represent the first demonstration that in vivo intrabursal administration of the antiapoptotic agent S1P itself effectively blocks the luteolytic action of PGF- $2 a$ in pregnant rats by decreasing caspase-2, -3 \& -8 activities, increasing the phosphorylation of AKT and TNF- $a$ and PECAM-1 expression.

\section{Materials and methods}

\section{Animals and Protocols}

Adult female Sprague-Dawley rats received food and water ad libitum and were housed at room temperature in a range of $21-23^{\circ} \mathrm{C}$ in a $12 \mathrm{~L}: 12 \mathrm{D}$ cycle. Animals were sacrificed by $\mathrm{CO} 2$ asphyxiation. The ovaries were removed and cleaned prior to subsequent assays. All experimental protocols were performed in accordance with the National Institutes of Health Guide for the Care and Use of Laboratory Animals and approved by the OHSU (Oregon Health and Science University) IACUC (Institutional Animal Care and Use Committee) and the IBYME (Instituto de Biología y Medicina Experimental) ethical committees. Stages of the estrous cycle were determined by daily examination of vaginal cytology, and rats were mated overnight at proestrus.

Day 1 of gestation was designated as the morning on which spermatozoa were found in a vaginal smear. Pregnant animals were divided in three main groups ( $n=4$ rats per group). 
Control untreated group (C0h): Rats were untreated at day 19 of pregnancy. Control PGF-2a group (PG4h \& PG36h): Anesthetized rats on day 19 of pregnancy were injected with the S1P vehicle PET (5\% PEG, 2.5\% ETOH, 0.8\% Tween 80) into the bursa of both ovaries ( $10 \mu \mathrm{l} /$ ovary) and 2 hours later they were injected IP with one dose of PGF-2a (400 $\mu \mathrm{g} / \mathrm{rat}$, Biogenesis, Bs As, Argentina). PGF-2a +S1P Group (PG+S4h \& PG+S36h): Rats on day 19 of pregnancy were injected with S1P into the bursa of both ovaries (10 $\mu \mathrm{g} / \mathrm{ovary}$, Sigma Chemical Co., St. Louis, MO), and 2 hours later they were also injected IP with one dose of PGF-2a.. Ovaries were collected at specific times (0, 4, and/or 36 hours) after PGF-2 $a$ administration in both Control PGF-2 $a$ and PGF-2 $a+$ S1P Group. Day 19 of pregnancy is selected for PGF- $2 a$ treatment since this is the time when the CL becomes more sensitive to PGF-2a action (Bussmann, 1989).

Corpora lutea were dissected from ovaries under a stereoscopic microscope as previously described in our laboratory (Andreu et al., 1998). Pools of CL (n=5-6 CL for each rat), were frozen in liquid nitrogen and stored at $-80{ }^{\circ} \mathrm{C}$ for protein isolation and steroid extraction. $0 \mathrm{~h}$ and $4 \mathrm{~h}$ timepoints for protein isolation and $0 \mathrm{~h}, 4 \mathrm{~h}$ and $36 \mathrm{~h}$ for steroid measurement. For ultrastructural morphology analysis by electronic microscopy (EM), CLs ( $n=3-4$ per group from different rats) were fixed in glutaraldehyde buffer. Also, half of one ovary was fixed in formalin to evaluate PECAM-1 expression, as well as, apoptosis. Samples at 0h, $4 \mathrm{~h}$ and $36 \mathrm{~h}$ post PGF-2 $a$ administration were used for ultrastructural analysis of the CL morphology and to analyze PECAM-1 expression and only 0/4h for apoptosis (TUNEL assay).

\section{Electronic Microscopy}

Isolated CLs were fixed for two hours by immersion in $2.5 \%(\mathrm{w} / \mathrm{v})$ glutaraldehyde prepared in $0.1 \mathrm{M}$ phosphate buffer, $\mathrm{pH}$ 7.4. Then, samples were washed with $0.1 \mathrm{M}$ phosphate buffer, $\mathrm{pH} 7.4$; and distilled water. After rinsing, samples were post-fixed with $1.5 \%$ osmium tetroxide for 90 minutes, washed with distilled water, and dehydrated with $50 \%$ ethanol for 10 minutes. Prior dehydration, the samples were pre-stained overnight with $1 \%$ uranyl acetate in $70 \%$ ethanol. The samples were then dehydrated with graded ethanol solutions followed by infiltration in propylene oxide and embedding in Epoxy Resin (Durcupan ACM, SPI \# 02809, Structure Probe, Inc./SPI Supplies, PA, USA). Ultrathin sections (700 nm thickness) were cut from the blocks using a Reichert-Jung ultramicrotome, collected on 300 mesh copper grids and post stained with Reynolds lead citrate solution (Reynolds, 1963). Ultrathin sections were then photographed with a Carl Zeiss 10C electron microscope at $80 \mathrm{kV}$ using a $35 \mathrm{~mm}$ Kodak $5302 \mathrm{film}$.

\section{PECAM-1 Immunohistochemistry (IHC)}

Ovaries from the different groups (C0h, PG4h, PG+S4h, PG36h \& PG+S36h) were fixed in $10 \%$ neutral buffered formalin for 1 week. Then tissues were dehydrated in a series of ethanol solutions (50, 70 and 100\%) and paraffin-embedded. Four $\mu \mathrm{m}$ sections were deparaffinized and hydrated through xylene and a graded series of ethanol. Endogenous peroxidases were then quenched with 25-min incubation in $3 \% \mathrm{H} 2 \mathrm{O} 2$. Sections were incubated in phosphate-buffered saline (PBS) prior to antigen retrieval $(0.1 \%$ Triton X-100 in PBS for $30 \mathrm{~min}$ plus a $30 \mathrm{~min}$ incubation in Proteinase K, $20 \mu \mathrm{g} / \mathrm{ml}$ ). Sections were placed in a blocking buffer (2\% BSA in PBS) for 20 minutes, and then incubated with the primary 
antibody anti-PECAM-1 (cat \# 550300, CD 31 purified mouse anti rat cd31 pecam-1 monoclonal, BD Pharmingen, CA, USA) in a concentration of 1:100 in PBS buffer for $1 \mathrm{~h}$ at room temperature and overnight at $4^{\circ} \mathrm{C}$. Primary antibody was detected using a biotinylated anti-mouse IgG secondary antibody (1:400; Vector Laboratories, Burlingame, CA, USA) and the Vector ABC-Elite Kit, visualized with DAB (diaminobenzidine) with a metal enhanced substrate as described by the manufacturer (1718096, Roche, Penzberg, Germany), and counterstained with hematoxylin. A negative control lacking primary antibody were processed on adjacent tissue sections.

\section{Luteal Progesterone Levels}

Steroids were extracted as previously described in our laboratory (Irusta et al., 2003). Progesterone content in $\mathrm{CL}$ was measured in rats from each group ( $\mathrm{n}=3-4$ rats per group; C0h, PG4h, PG+S4h, PG36h \& PG+S36h). A pool of 3-4 CLs was used to represent luteal progesterone content in each rat. CLs were homogenized in acetone with Ultra-Turrax (IKA Werk, Breisgau, Germany). Known quantities of labeled progesterone (3H-progesterone) in acetone (approximately $3000 \mathrm{cpm}$ ), were added to each sample as internal standard. An aliquot was taken from each homogenate for protein measurement. After homogenization, the samples were centrifuged $(1,600 \mathrm{x}$ g for $10 \mathrm{~min})$ and the resultant supernatant was evaporated to dryness. Following the addition of distilled water and vortexing, the samples were twice extracted with diethyl ether and the upper ether phase was transferred to conical tubes and again evaporated to dryness. The remaining residue was dissolved in methanol and, after adding distilled water, the samples were submitted to a solvent partition with $\mathrm{n}$ hexane and dichloromethane and the upper layer was discarded and the lower phase evaporated. Finally, samples were stored in distilled water for later analysis by radioimmunoassay (Irusta et al., 2003) and each sample was tested in duplicate.

\section{Caspase-2, -3, -8, and -9 Activity Assays}

From each rat (n=3-4) a pool of CL per ovary (C0h, PG4h \& PG+S4h) was used to evaluate enzyme activity ( $n=3-4$ ovaries/per group). A fluorometric assay kit (630225, Clontech, CA, USA), which contains fluorogenic substrates specific for different caspases $(-2,-3,-8$ and $-9)$, immobilized in separate wells, was used following the procedure previously described by our laboratories (Peluffo et al., 2005; Peluffo et al., 2006). Twenty $\mu \mathrm{g}$ (caspase-2 and -3) or $40 \mu \mathrm{g}$ (caspase-8 and -9) of the extracted protein from each pool of CL was added in homogenization buffer to the wells and each concentration was tested in duplicate. The plate was incubated in the fluorescence plate reader at $37^{\circ} \mathrm{C}$ for 3 hours and fluorescence was read every 10 minutes. The activity was determined by fluorometric detection (Ex: 380nm, Em: 460nm) and the negative control (blank, without sample) was subtracted from all the samples. The two-hour incubation point was selected for analyses because it was located on the linear section of the activity curve. Baseline values of negative controls and samples with specific caspase inhibitors did not increase during the $2 \mathrm{hr}$ interval.

\section{Apoptotic Cell Analysis (TUNEL)}

Serial $4 \mu \mathrm{m}$ sections of paraffin-embedded fixed ovaries $(\mathrm{n}=3-4)$ from the different groups (C0h, PG4h \& PG+S4h) were used. Nuclear DNA fragmentation in luteal cells was detected using the DeadEnd Colorimetric TUNEL System (G7130, Promega, Madison, WI, USA), 
following the manufacturer's instructions with minor modifications as previously described (Peluffo et al., 2005; Peluffo et al., 2006). A microscope with a 100X objective was used and three randomly selected fields were analyzed from each CL section (3 CLs per section/ ovary, 3-4 ovaries per stage). Results were expressed as the percentage of apoptotic cells.

\section{TNF- $a$ ELISA}

Concentrations of TNF-a in homogenized CL from the different treatment groups (COh, PG4h \& PG+S4h) were quantitated by enzyme-linked immunosorbent assay (Quantikine Rat TNF-alpha/TNFSF1A immunoassay, Cat \# RTA00, R\&D Systems Inc., MN, USA). Based on the manufacturer's instructions, $120 \mu \mathrm{g}$ of the extracted proteins from the CL were added into the plate ( $\mathrm{n}=3-4$ ovaries/per group), where a monoclonal antibody specific for rat TNF-a was pre- coated onto each well, and incubated for 2 hours at room temperature. After washing away any unbound substances, an enzyme-linked polyclonal antibody specific for rat TNF-a was added to the wells and the plate was incubated for 2 hours at room temperature. Then, following a wash, a substrate solution was added to the wells and the plate was incubated in the dark 30 minutes at room temperature, and the reaction ended by adding a stop solution. The intensity of the color measured was in proportion to the amount of rat TNF- $a$ bound in the initial step. The TNF- $a$ protein levels were determined by absorbance, at $450 \mathrm{~nm}$, against a standard curve. Each sample was tested in duplicate and negative controls (blanks, without sample) were subtracted.

\section{PAKT ELISA}

An ELISA kit was used to detect and quantify the level of Akt protein that is phosphorylated at serine residue 473 (CBA005, Calbiochem) in CL from the different groups (C0h, PG4h \& $\mathrm{PG}+\mathrm{S} 4 \mathrm{~h}$ ) was used following the manufacturer's procedure. Similar to the caspase activity assay, a pool of CL from each ovary was used to evaluate the levels of the phosphorylated form of AKT ( $n=3-4$ ovaries/per group). Thirty $\mu \mathrm{g}$ of the extracted protein from each pool of CL diluted in stardand diluent was added into the wells, that were coated with a monoclonal antibody specific for Akt1 (regardless of phosphorylation state), and the plate was incubated at room temperature for 2 hours. After washing, a rabbit antibody anti-Akt (pSer473) was added to the wells and the plate was incubated for 1 hour at room temperature. After removal of excess detection antibody, a horseradish peroxidase-labeled anti-rabbit IgG (anti-rabbit IgG-HRP) was added and the plate was incubated for 30 minutes at room temperature. Then, after rinsing a stabilized chromogen was added, and the plate was incubated in the dark for $30 \mathrm{~min}$ at room temperature, and the reaction ended by adding a stop solution. The AKT (pSer473) levels were determined by absorbance, at $450 \mathrm{~nm}$, against a standard curve. Each sample was tested in duplicate and the plate was blanked against a reaction tube containing only the stabilized chromogen and the stop solution.

\section{Western blotting}

After boiling for $5 \mathrm{~min}$, extracted proteins from the different CL groups (40 $\mu \mathrm{g}$ protein, C0h, PG4h \& PG+S4h) were separated by $10 \%$ SDS PAGE and transferred to a nitrocellulose membrane using an electroblotting apparatus as previously described (Peluffo et al., 2007; Abramovich et al., 2009). Non-specific binding sites were blocked overnight (ON) in TBS (4 mM Tris-Cl, pH 7.5, $100 \mathrm{mM} \mathrm{NaCl}$ ) containing low-fat powdered milk (5\%) and Tween 
$20(0.5 \%)$ at $4^{\circ} \mathrm{C}$. The membranes were then incubated overnight with the appropriate antirabbit primary antibodies (AKT: Cat \# 9272 Cell Signaling, Boston, MA or phospho AKT, phosphorylated at serine residue 473: Cat \# 7985 Santa Cruz Biotechnology, Santa Cruz, CA). Protein bands were visualized by incubating the blots for 1 hour with peroxidaseconjugated secondary anti-rabbit IgG (1:1000, Cat \# A4914 Sigma Chemical Co., St. Louis, MO). Finally, the membranes were incubated with Western Lightning. Chemiluminescence Reagent Plus (cat \# NEL104, PerkinElmer Life Sciences, Inc. Boston, MA) for 1 min and exposed to X-ray film in a dark room. Protein expression was quantified by densitometric analysis using Scion Image Software for Windows (Scion Corporation, Worman's Mill, CT). Consistency of protein loading was evaluated by staining the membranes with Ponceau-S and the density in each specific band was normalized to the density of an internal control, GAPDH (1:10000, Cat \# 2118 Cell Signaling Boston, MA).

\section{Statistical Analysis}

Statistical analyses were performed using the ANOVA Test for comparison between timepoints followed by Student-Newman-Keuls method using the Sigma Stat software package (SPSS, Chicago, IL). Differences were considered significant at $\mathrm{p}<0.05$. Percentage data were analyzed using the ANOVA Test (non parametric, Kruskal-Wallis statistic) for comparison between timepoints followed by Dunn's Multiple Comparison method.

\section{Acknowledgments}

This research was supported by NIH-FIRCA RO3-TW007041 (RLS, MT, MCP, FH), ANPCYT BID 1728 OC-AR PICT 2004:05-26047 (MT, MCP, FH), UBA EX237 (MT), Roemmers Foundation (MT), NIH-NCCR RR00163 (RLS) and NIH-HD20869 (RLS).

The authors are grateful for the expert contributions of the animal care staff of the Division of Animal Resources at IBYME, especially to Victor Fernandez and Paola Garcette. We also want to thank Mrs Emerita Jorge Vilela for her technical assistance with the electronic microscopy studies and the use of the LANAIS-MIE instruments (UBACONICET).

\section{References}

Abdo M, Hisheh S, Dharmarajan A. Role of tumor necrosis factor-alpha and the modulating effect of the caspases in rat corpus luteum apoptosis. Biol Reprod. 2003; 68:1241-1248. [PubMed: 12606464]

Abdo MA, Richards A, Atiya N, Singh B, Parkinson S, Hisheh S, Dharmarajan AM. Inhibitors of caspase homologues suppress an apoptotic phenotype in cultured rabbit corpora lutea. Reprod Fertil Dev. 2001; 13:395-403. [PubMed: 11833936]

Abramovich D, Irusta G, Parborell F, Tesone M. Intrabursal injection of vascular endothelial growth factor trap in eCG-treated prepubertal rats inhibits proliferation and increases apoptosis of follicular cells involving the PI3K/AKT signaling pathway. Fertil Steri. 2009 Mar 26. Epub ahead of print.

Abramovich D, Parborell F, Tesone M. Effect of a vascular endothelial growth factor (VEGF) inhibitory treatment on the folliculogenesis and ovarian apoptosis in gonadotropin-treated prepubertal rats. Biol Reprod. 2006; 75:434-441. [PubMed: 16775226]

Alnemri ES, Livingston DJ, Nicholson DW, Salvesen G, Thornberry NA, Wong WW, Yuan J. Human ICE/CED-3 protease nomenclature. Cell. 1996; 87:171. [PubMed: 8861900]

Alvarez SE, Milstien S, Spiegel S. Autocrine and paracrine roles of sphingosine-1-phosphate. Trends Endocrinol Metab. 2007; 18:300-307. [PubMed: 17904858] 
Andreu C, Parborell F, Vanzulli S, Chemes H, Tesone M. Regulation of follicular luteinization by a gonadotropin-releasing hormone agonist: relationship between steroidogenesis and apoptosis. Mol Reprod Dev. 1998; 51:287-294. [PubMed: 9771649]

Bacci ML, Barazzoni AM, Forni M, Costerbosa GL. In situ detection of apoptosis in regressing corpus luteum of pregnant sow: evidence of an early presence of DNA fragmentation. Domest Anim Endocrinol. 1996; 13:361-372. [PubMed: 8839629]

Balthasar S, Bergelin N, Lof C, Vainio M, Andersson S, Tornquist K. Interactions between sphingosine-1-phosphate and vascular endothelial growth factor signalling in ML-1 follicular thyroid carcinoma cells. Endocr Relat Cancer. 2008; 15:521-534. [PubMed: 18509004]

Beg AA, Baltimore D. An essential role for NF-kappaB in preventing TNF-alpha-induced cell death. Science. 1996; 274:782-784. [PubMed: 8864118]

Boone DL, Tsang BK. Caspase-3 in the rat ovary: localization and possible role in follicular atresia and luteal regression. Biol Reprod. 1998; 58:1533-1539. [PubMed: 9623616]

Bowen J, Keyes P, Warren J, Townson D. Prolactin-induced regression of the rat corpus luteum: expression of monocyte chemoattractant protein-1 and invasion of macrophages. Biol Reprod. 1996; 54:1120-1127. [PubMed: 8722634]

Bowen-Shauver JM, Gibori G. The Corpus Luteum of Pregnancy. 2004:201-230.

Brannstrom M, Friden B. Immune regulation of corpus luteum function. Semin Reprod Endocrinol. 1997; 15:363-370. [PubMed: 9580945]

Bussmann LE. Prostaglandin F-2 alpha receptors in corpora lutea of pregnant rats and relationship with induction of 20 alpha-hydroxysteroid dehydrogenase. J Reprod Fertil. 1989; 85:331-341. [PubMed: 2703980]

Carambula SF, Pru JK, Lynch MP, Matikainen T, Goncalves PB, Flavell RA, Tilly JL, Rueda BR. Prostaglandin F2alpha- and FAS-activating antibody-induced regression of the corpus luteum involves caspase-8 and is defective in caspase-3 deficient mice. Reprod Biol Endocrinol. 2003; 1:15. [PubMed: 12657159]

Chae SS, Proia RL, Hla T. Constitutive expression of the S1P1 receptor in adult tissues. Prostaglandins Other Lipid Mediat. 2004; 73:141-150. [PubMed: 15165038]

Channing CP. Steroidogenesis and morphology of human ovarian cell types in tissue culture. J Endocrinol. 1969a; 45:297-308. [PubMed: 5824089]

Channing CP. Tissue culture of equine ovarian cell types: culture methods and morphology. $\mathrm{J}$ Endocrinol. 1969b; 43:381-390. [PubMed: 5779612]

Chinnaiyan AM, Dixit VM. The cell-death machine. Curr Biol. 1996; 6:555-562. [PubMed: 8805273]

Cryns V, Yuan J. Proteases to die for. Genes Dev. 1998; 12:1551-1570. [PubMed: 9620844]

Cuvillier O, Levade T. Sphingosine 1-phosphate antagonizes apoptosis of human leukemia cells by inhibiting release of cytochrome $\mathrm{c}$ and Smac/DIABLO from mitochondria. Blood. 2001; 98:28282836. [PubMed: 11675357]

Cuvillier O, Pirianov G, Kleuser B, Vanek PG, Coso OA, Gutkind S, Spiegel S. Suppression of ceramide-mediated programmed cell death by sphingosine-1-phosphate. Nature. 1996; 381:800803. [PubMed: 8657285]

Davis JS, Rueda BR. The corpus luteum: an ovarian structure with maternal instincts and suicidal tendencies. Front Biosci. 2002; 7:d1949-d1978. [PubMed: 12161347]

DeLisser HM, Newman PJ, Albelda SM. Platelet endothelial cell adhesion molecule (CD31). Curr Top Microbiol Immunol. 1993; 184:37-45. [PubMed: 8313722]

Engelman JA, Luo J, Cantley LC. The evolution of phosphatidylinositol 3-kinases as regulators of growth and metabolism. Nat Rev Genet. 2006; 7:606-619. [PubMed: 16847462]

Ferrara N, Damico L, Shams N, Lowman H, Kim R. Development of ranibizumab, an anti-vascular endothelial growth factor antigen binding fragment, as therapy for neovascular age-related macular degeneration. Retina. 2006; 26:859-870. [PubMed: 17031284]

Friedman A, Weiss S, Levy N, Meidan R. Role of tumor necrosis factor alpha and its type I receptor in luteal regression: induction of programmed cell death in bovine corpus luteum-derived endothelial cells. Biol Reprod. 2000; 63:1905-1912. [PubMed: 11090464] 
Gao N, Flynn DC, Zhang Z, Zhong XS, Walker V, Liu KJ, Shi X, Jiang BH. G1 cell cycle progression and the expression of $\mathrm{G} 1$ cyclins are regulated by PI3K/AKT/mTOR/p70S6K1 signaling in human ovarian cancer cells. Am J Physiol Cell Physiol. 2004; 287:C281-C291. [PubMed: 15028555]

Gao N, Zhang Z, Jiang BH, Shi X. Role of PI3K/AKT/mTOR signaling in the cell cycle progression of human prostate cancer. Biochem Biophys Res Commun. 2003; 310:1124-1132. [PubMed: 14559232]

Gaytan F, Bellido C, Morales C, Sanchez-Criado JE. Both prolactin and progesterone in proestrus are necessary for the induction of apoptosis in the regressing corpus luteum of the rat. Biol Reprod. 1998; 59:1200-1206. [PubMed: 9780328]

Goodman SB, Kugu K, Chen SH, Preutthipan S, Tilly KI, Tilly JL, Dharmarajan AM. Estradiolmediated suppression of apoptosis in the rabbit corpus luteum is associated with a shift in expression of bcl-2 family members favoring cellular survival. Biol Reprod. 1998; 59:820-827. [PubMed: 9746731]

Goyeneche AA, Harmon JM, Telleria CM. Cell death induced by serum deprivation in luteal cells involves the intrinsic pathway of apoptosis. Reproduction. 2006; 131:103-111. [PubMed: 16388014]

Guo K, Wolf V, Dharmarajan AM, Feng Z, Bielke W, Saurer S, Friis R. Apoptosis-associated gene expression in the corpus luteum of the rat. Biol Reprod. 1998; 58:739-746. [PubMed: 9510961]

Guo Y, Srinivasula SM, Druilhe A, Fernandes-Alnemri T, Alnemri ES. Caspase-2 induces apoptosis by releasing proapoptotic proteins from mitochondria. J Biol Chem. 2002; 277:13430-13437. [PubMed: 11832478]

Hancke K, Strauch O, Kissel C, Gobel H, Schafer W, Denschlag D. Sphingosine 1-phosphate protects ovaries from chemotherapy-induced damage in vivo. Fertil Steril. 2007; 87:172-177. [PubMed: 17081530]

Hansel W, Blair RM. Bovine corpus luteum: a historic overview and implications for future research. Theriogenology. 1996; 45:1267-1294. [PubMed: 16727883]

Hasumoto K, Sugimoto Y, Yamasaki A, Morimoto K, Kakizuka A, Negishi M, Ichikawa A. Association of expression of mRNA encoding the PGF2 alpha receptor with luteal cell apoptosis in ovaries of pseudopregnant mice. J Reprod Fertil. 1997; 109:45-51. [PubMed: 9068412]

Hazzard TM, Stouffer RL. Angiogenesis in ovarian follicular and luteal development. Baillieres Best Pract Res Clin Obstet Gynaecol. 2000; 14:883-900. [PubMed: 11141339]

Henkes LE, Sullivan BT, Lynch MP, Kolesnick R, Arsenault D, Puder M, Davis JS, Rueda BR. Acid sphingomyelinase involvement in tumor necrosis factor alpha-regulated vascular and steroid disruption during luteolysis in vivo. Proc Natl Acad Sci U S A. 2008; 105:7670-7675. [PubMed: 18505843]

Hong G, Baudhuin LM, Xu Y. Sphingosine-1-phosphate modulates growth and adhesion of ovarian cancer cells. FEBS Lett. 1999; 460:513-518. [PubMed: 10556527]

Igarashi J, Erwin PA, Dantas AP, Chen H, Michel T. VEGF induces S1P1 receptors in endothelial cells: Implications for cross-talk between sphingolipid and growth factor receptors. Proc Natl Acad Sci U S A. 2003; 100:10664-10669. [PubMed: 12963813]

Irusta G, Parborell F, Peluffo M, Manna PR, Gonzalez-Calvar SI, Calandra R, Stocco DM, Tesone M. Steroidogenic acute regulatory protein in ovarian follicles of gonadotropin-stimulated rats is regulated by a gonadotropin-releasing hormone agonist. Biol Reprod. 2003; 68:1577-1583. [PubMed: 12606484]

Jiang BH, Liu LZ. PI3K/PTEN signaling in tumorigenesis and angiogenesis. Biochim Biophys Acta. 2008; 1784:150-158. [PubMed: 17964232]

Khan SM, Dauffenbach LM, Yeh J. Mitochondria and caspases in induced apoptosis in human luteinized granulosa cells. Biochem Biophys Res Commun. 2000; 269:542-545. [PubMed: 10708590]

Koos RD. Ovarian angiogenesis. 1993:433-453.

Krajewska M, Wang HG, Krajewski S, Zapata JM, Shabaik A, Gascoyne R, Reed JC. Immunohistochemical analysis of in vivo patterns of expression of CPP32 (Caspase-3), a cell death protease. Cancer Res. 1997; 57:1605-1613. [PubMed: 9108467] 
Kuranaga E, Kanuka H, Bannai M, Suzuki M, Nishihara M, Takahashi M. Fas/Fas ligand system in prolactin-induced apoptosis in rat corpus luteum: possible role of luteal immune cells. Biochem Biophys Res Commun. 1999; 260:167-173. [PubMed: 10381361]

Liszewska E, Rekawiecki R, Kotwica J. Effect of progesterone on the expression of bax and bcl-2 and on caspase activity in bovine luteal cells. Prostaglandins Other Lipid Mediat. 2005; 78:67-81. [PubMed: 16303606]

Maines LW, French KJ, Wolpert EB, Antonetti DA, Smith CD. Pharmacologic manipulation of sphingosine kinase in retinal endothelial cells: implications for angiogenic ocular diseases. Invest Ophthalmol Vis Sci. 2006; 47:5022-5031. [PubMed: 17065523]

Martin SJ, Green DR. Protease activation during apoptosis: death by a thousand cuts? Cell. 1995; 82:349-352. [PubMed: 7634323]

May MJ, Ghosh S. IkappaB kinases: kinsmen with different crafts. Science. 1999; 284:271-273. [PubMed: 10232975]

Milvae RA, Hinckley ST, Carlson JC. Luteotropic and luteolytic mechanisms in the bovine corpus luteum. Theriogenology. 1996; 45:1327-1349. [PubMed: 16727885]

Morita Y, Perez GI, Paris F, Miranda SR, Ehleiter D, Haimovitz-Friedman A, Fuks Z, Xie Z, Reed JC, Schuchman EH, Kolesnick RN, Tilly JL. Oocyte apoptosis is suppressed by disruption of the acid sphingomyelinase gene or by sphingosine-1-phosphate therapy. Nat Med. 2000; 6:1109-1114. [PubMed: 11017141]

Nicholson DW. Caspase structure, proteolytic substrates, and function during apoptotic cell death. Cell Death Differ. 1999; 6:1028-1042. [PubMed: 10578171]

Niswender GD, Nett TM. Corpus luteum and its control in infraprimate species. 1994:781-816.

Osawa Y, Banno Y, Nagaki M, Brenner DA, Naiki T, Nozawa Y, Nakashima S, Moriwaki H. TNFalpha-induced sphingosine 1-phosphate inhibits apoptosis through a phosphatidylinositol 3kinase/Akt pathway in human hepatocytes. J Immunol. 2001; 167:173-180. [PubMed: 11418646]

Oyama O, Sugimoto N, Qi X, Takuwa N, Mizugishi K, Koizumi J, Takuwa Y. The lysophospholipid mediator sphingosine-1-phosphate promotes angiogenesis in vivo in ischaemic hindlimbs of mice. Cardiovasc Res. 2008; 78:301-307. [PubMed: 18187460]

Papadopoulos V, Dharmarajan AM, Li H, Culty M, Lemay M, Sridaran R. Mitochondrial peripheraltype benzodiazepine receptor expression. Correlation with gonadotropin-releasing hormone (GnRH) agonist-induced apoptosis in the corpus luteum. Biochem Pharmacol. 1999; 58:13891393. [PubMed: 10513982]

Parborell F, Abramovich D, Tesone M. Intrabursal administration of the antiangiopoietin 1 antibody produces a delay in rat follicular development associated with an increase in ovarian apoptosis mediated by changes in the expression of BCL2 related genes. Biol Reprod. 2008; 78:506-513. [PubMed: 17989359]

Payne SG, Milstien S, Spiegel S. Sphingosine-1-phosphate: dual messenger functions. FEBS Lett. 2002; 531:54-57. [PubMed: 12401202]

Peluffo MC, Bussmann L, Stouffer RL, Tesone M. Expression of caspase-2, -3, -8 and -9 proteins and enzyme activity in the corpus luteum of the rat at different stages during the natural estrous cycle. Reproduction. 2006; 132:465-475. [PubMed: 16940287]

Peluffo MC, Stouffer RL, Tesone M. Activity and expression of different members of the caspase family in the rat corpus luteum during pregnancy and postpartum. Am J Physiol Endocrinol Metab. 2007; 293:E1215-E1223. [PubMed: 17726144]

Peluffo MC, Young KA, Stouffer RL. Dynamic Expression of Caspase-2, -3, -8, and -9 Proteins and Enzyme Activity, But Not Messenger Ribonucleic Acid, in the Monkey Corpus Luteum during the Menstrual Cycle. J Clin Endocrinol Metab. 2005; 90:2327-2335. [PubMed: 15671090]

Petroff MG, Petroff BK, Pate JL. Expression of cytokine messenger ribonucleic acids in the bovine corpus luteum. Endocrinology. 1999; 140:1018-1021. [PubMed: 9927338]

Pharriss B. Prostaglandin induction of luteolysis. Ann N Y Acad Sci. 1971; 180:436-444. [PubMed: 4999662]

Pharriss BB, Tillson SA, Erickson RR. Prostaglandins in luteal function. Recent Prog Horm Res. 1972; 28:51-89. [PubMed: 4569232] 
Pharriss BB, Wyngarden LJ. The effect of prostaglandin F 2alpha on the progestogen content of ovaries from pseudopregnant rats. Proc Soc Exp Biol Med. 1969; 130:92-94. [PubMed: 5762534]

Pru JK, Hendry IR, Davis JS, Rueda BR. Soluble Fas ligand activates the sphingomyelin pathway and induces apoptosis in luteal steroidogenic cells independently of stress-activated p38(MAPK). Endocrinology. 2002; 143:4350-4357. [PubMed: 12399431]

Reynolds ES. The use of lead citrate at high $\mathrm{pH}$ as an electron-opaque stain in electron microscopy. J Cell Biol. 1963; 17:208-212. [PubMed: 13986422]

Rueda BR, Hendry IR, Tilly JL, Hamernik DL. Accumulation of caspase-3 messenger ribonucleic acid and induction of caspase activity in the ovine corpus luteum following prostaglandin F2alpha treatment in vivo. Biol Reprod. 1999; 60:1087-1092. [PubMed: 10208968]

Sanchez T, Hla T. Structural and functional characteristics of S1P receptors. J Cell Biochem. 2004; 92:913-922. [PubMed: 15258915]

Sanchez T, Skoura A, Wu MT, Casserly B, Harrington EO, Hla T. Induction of vascular permeability by the sphingosine-1-phosphate receptor-2 (S1P2R) and its downstream effectors ROCK and PTEN. Arterioscler Thromb Vasc Biol. 2007; 27:1312-1318. [PubMed: 17431187]

Schwartz BM, Hong G, Morrison BH, Wu W, Baudhuin LM, Xiao YJ, Mok SC, Xu Y. Lysophospholipids increase interleukin-8 expression in ovarian cancer cells. Gynecol Oncol. 2001; 81:291-300. [PubMed: 11330965]

Spiegel S, Milstien S. Sphingosine-1-phosphate: signaling inside and out. FEBS Lett. 2000; 476:5557. [PubMed: 10878250]

Spiegel S, Milstien S. Exogenous and intracellularly generated sphingosine 1-phosphate can regulate cellular processes by divergent pathways. Biochem Soc Trans. 2003a; 31:1216-1219. [PubMed: 14641029]

Spiegel S, Milstien S. Sphingosine-1-phosphate: an enigmatic signalling lipid. Nat Rev Mol Cell Biol. 2003b; 4:397-407. [PubMed: 12728273]

Stocco C, Telleria C, Gibori G. The molecular control of corpus luteum formation, function, and regression. Endocr Rev. 2007; 28:117-149. [PubMed: 17077191]

Stouffer RL. The Function and regulation of Cell Populations Comprising the Corpus Luteum during the Ovarian Cycle. 2004:169-184.

Telleria CM, Goyeneche AA, Cavicchia JC, Stati AO, Deis RP. Apoptosis induced by antigestagen RU486 in rat corpus luteum of pregnancy. Endocrine. 2001; 15:147-155. [PubMed: 11720240]

Terranova PF, Rice VM. Review: cytokine involvement in ovarian processes. Am J Reprod Immunol. 1997; 37:50-63. [PubMed: 9138453]

Thornberry NA, Lazebnik Y. Caspases: enemies within. Science. 1998; 281:1312-1316. [PubMed: 9721091]

Wang CY, Mayo MW, Baldwin AS Jr. TNF- and cancer therapy-induced apoptosis: potentiation by inhibition of NF-kappaB. Science. 1996; 274:784-787. [PubMed: 8864119]

Wu M, Lee H, Bellas RE, Schauer SL, Arsura M, Katz D, FitzGerald MJ, Rothstein TL, Sherr DH, Sonenshein GE. Inhibition of NF-kappaB/Rel induces apoptosis of murine B cells. EMBO J. 1996; 15:4682-4690. [PubMed: 8887559]

Xia P, Gamble JR, Rye KA, Wang L, Hii CS, Cockerill P, Khew-Goodall Y, Bert AG, Barter PJ, Vadas MA. Tumor necrosis factor-alpha induces adhesion molecule expression through the sphingosine kinase pathway. Proc Natl Acad Sci U S A. 1998; 95:14196-14201. [PubMed: 9826677]

Xia P, Wang L, Gamble JR, Vadas MA. Activation of sphingosine kinase by tumor necrosis factoralpha inhibits apoptosis in human endothelial cells. J Biol Chem. 1999; 274:34499-34505. [PubMed: 10567432]

Xu Y, Fang XJ, Casey G, Mills GB. Lysophospholipids activate ovarian and breast cancer cells. Biochem J. 1995; 309 (Pt 3):933-940. [PubMed: 7639713]

Xu Y, Shen Z, Wiper DW, Wu M, Morton RE, Elson P, Kennedy AW, Belinson J, Markman M, Casey G. Lysophosphatidic acid as a potential biomarker for ovarian and other gynecologic cancers. JAMA. 1998; 280:719-723. [PubMed: 9728644]

$\mathrm{Xu}$ Y, Xiao YJ, Baudhuin LM, Schwartz BM. The role and clinical applications of bioactive lysolipids in ovarian cancer. J Soc Gynecol Investig. 2001; 8:1-13. 
Yadav VK, Lakshmi G, Medhamurthy R. Prostaglandin F2alpha-mediated activation of apoptotic signaling cascades in the corpus luteum during apoptosis: involvement of caspase-activated DNase. J Biol Chem. 2005; 280:10357-10367. [PubMed: 15623530]

Zhao Y, Burbach JA, Roby KF, Terranova PF, Brannian JD. Macrophages are the major source of tumor necrosis factor alpha in the porcine corpus luteum. Biol Reprod. 1998; 59:1385-1391. [PubMed: 9828182] 

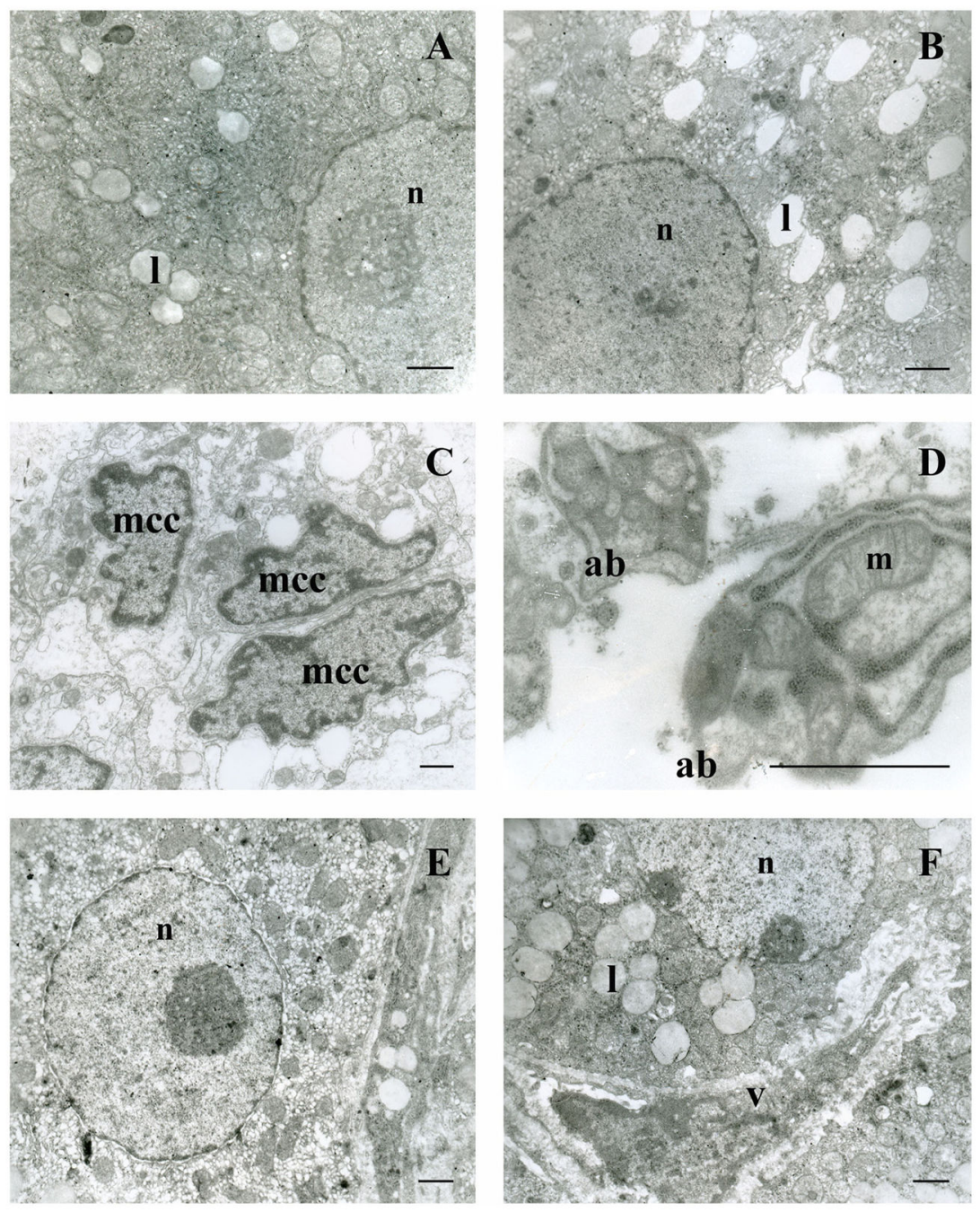

Figure 1.

Ultrastructural features of the rat CL after $36 \mathrm{~h}$ of PGF-2a (PG) administration. Rats were intrabursa treated with S1P (S) (PG + S36h) or the vehicle PET (PG36h), two hours prior PGF-2a injection. C0h: Rats were untreated at day 19 of pregnancy.

Photomicrographs showing ultrastructural aspects of the corpus luteum obtained from the different groups: C0h (A-B), PG36h (C-D) and PG+S36h (E-F). Typical morphological features of apoptosis evident after PGF-2a treatment: the presence of multiple nucleus with marginated and condensed chromatin, as well as the presence of apoptotic bodies; whereas not in the control group or the S1P group. For all: $\mathrm{n}=$ nucleus; $\mathrm{m}=$ =mitochondrion; $\mathrm{ab}=$ apoptotic body; 1 = lipid droplets; mcc=marginated and condensed chromatin; v=blood vessel. Each bar represents $1 \mu \mathrm{m}$ in all the panels. 

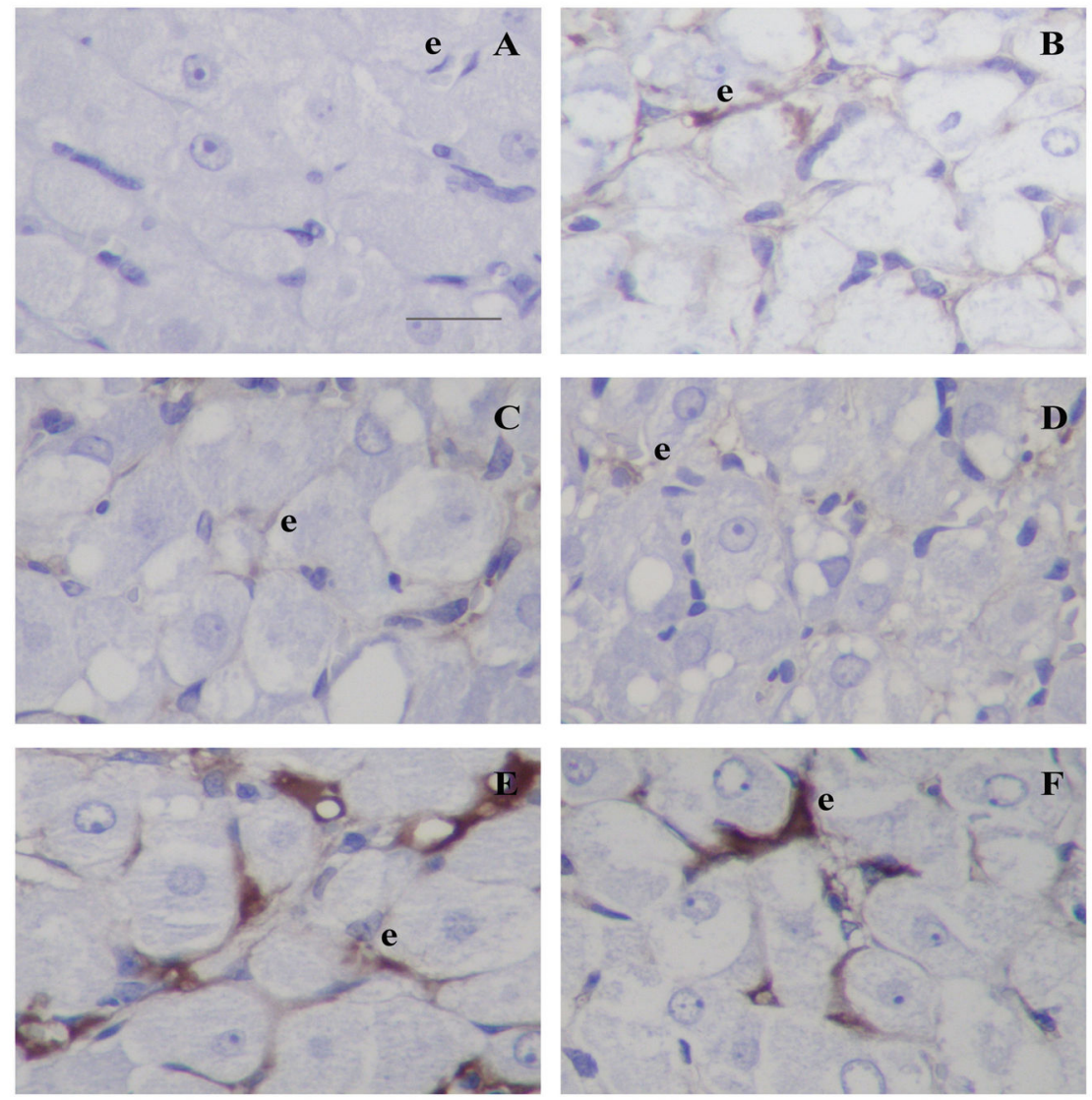

Figure 2.

Immunohistochemistry for PECAM-1 in the rat CL after $4 \mathrm{~h}$ or $36 \mathrm{~h}$ of PGF-2a (PG) administration. Rats were intrabursa treated with S1P (S) (PG+S4h or S36h) or the vehicle PET (PG4h or PG36h), two hours prior PGF-2a injection. C0h: Rats were untreated at day 19 of pregnancy.

Microscope images from C0h (B), PG4h (C), PG36h (D), PG+S4h (E) and PG+S36h (F). Compared to the negative control incubated without the primary antibody (A). Staining was evident in the endothelial cells (e), but not in the luteal cells (small and large), nor in the stroma. Scale bar $=20 \mu \mathrm{m}$. PECAM-1 was highly expressed in the CL of the C0h, PG+S4h and PG+S36h samples. While, little or no expression of PECAM-1 was detected in the CL after PGF-2a administration (PG4h and PG36h). 


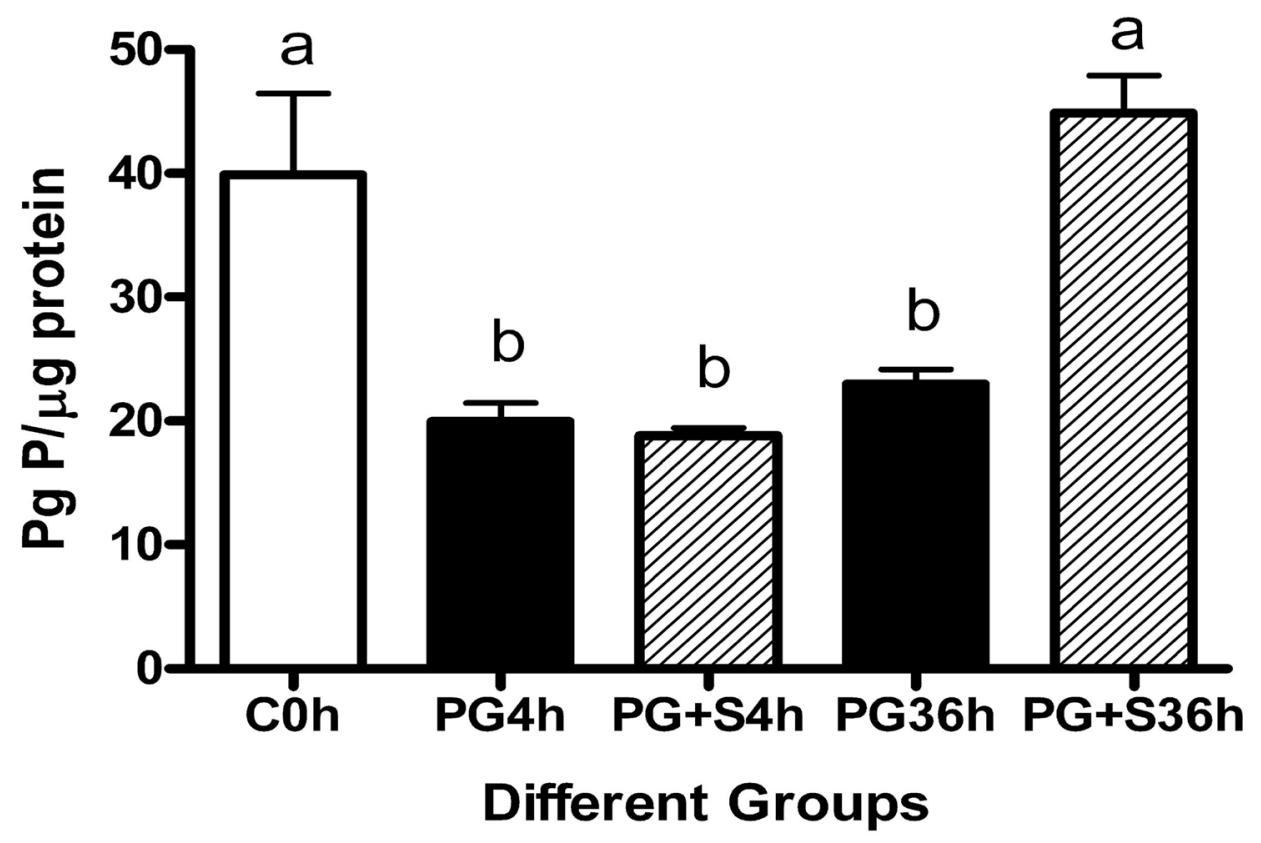

Figure 3.

Luteal progesterone (P) levels (mean \pm SEM) at different times (4h or 36h) after PGF-2a (PG) administration. Rats were intrabursa treated with S1P (S) (PG+S4h or S36h) or with the vehicle PET (PG4h or 36h), two hours prior PGF-2a injection. C0h: Rats were untreated at day 19 of pregnancy. Different letters $(a, b, c)$ over standard error bars indicate significant differences $(p<0.05)$ between groups $(n=3-4$ per group). 
A

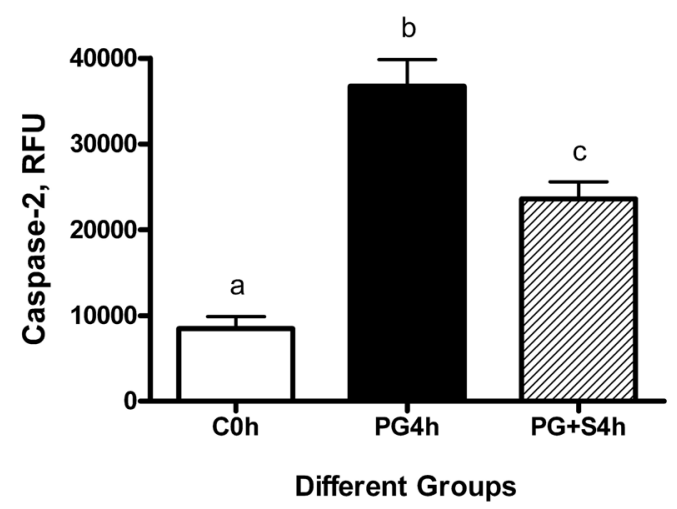

$\mathrm{C}$

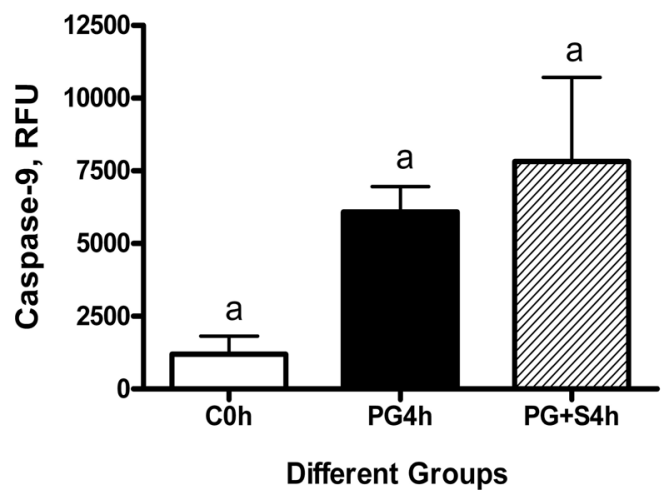

$\mathrm{B}$

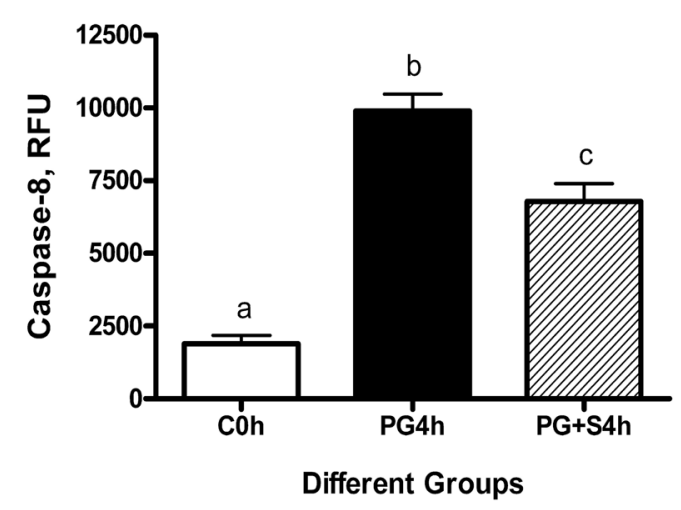

$\mathrm{D}$

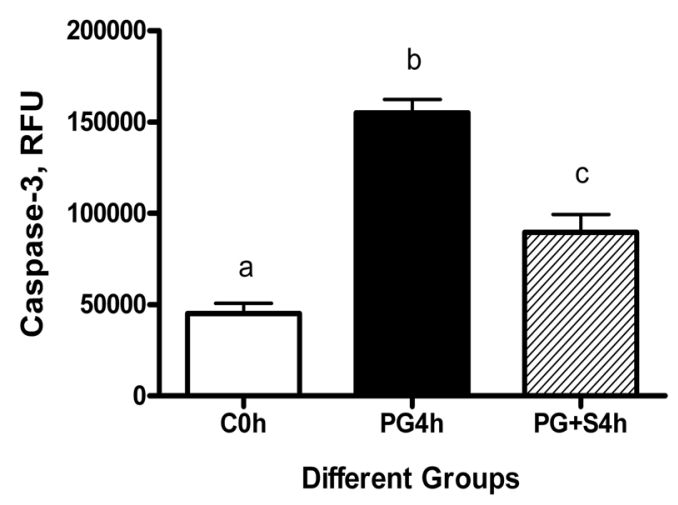

Figure 4.

Enzyme activity levels (mean \pm SEM) for the initiator caspases $-2(A),-8(B),-9$ (C) and the effector caspase-3 (D) in the rat CL after $4 \mathrm{~h}$ of PGF-2a (PG) administration. Rats were treated with S1P (S) (PG+S4h) or the vehicle PET (PG4h), two hours prior PGF-2a injection. COh: Rats were untreated at day 19 of pregnancy. Bars with different letters (a, b, c) represent a significant difference $(\mathrm{p}<0.05)$ in the activity between groups ( $\mathrm{n}=3-4$ per group). The activity is expressed in RFU (Relative Fluorescence Units). 
A
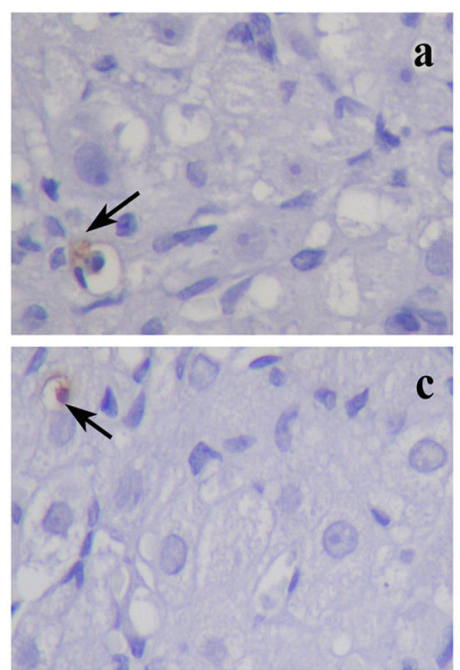

B

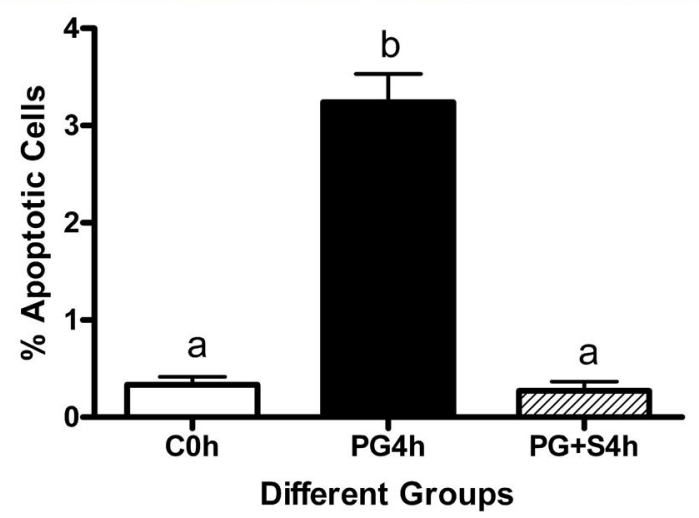

Figure 5.

In situ $3^{\prime}$ end labeling (TUNEL) of rat CL obtained from different treatment groups (panel A). C0h (a), PG4h (b) and PG+S4h (c); Cells showing advanced signs of apoptosis were positively stained in the TUNEL assay (arrows). Negative control without the TdT enzyme, showed no staining (d). Bar $=20 \mu \mathrm{m}$. Panel B: TUNEL analysis expressed as the percent of apoptotic cells in the CL. Different letters ( $a, b, c)$ represent significant differences $(\mathrm{p}<0.05)$ between the different groups. Six randomly selected fields were analyzed from each CL section (3-4 CL per section/ovary, 4 ovaries per group). 

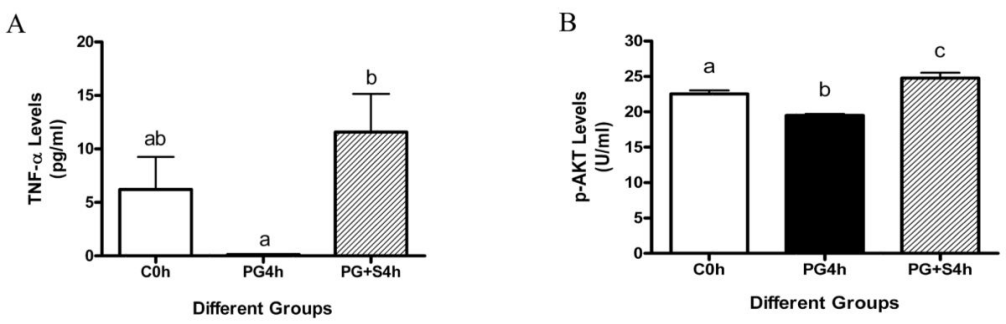

Figure 6.

Levels of TNF-a protein (Panel A) and phosphorylated-Akt (Panel B) as measured by immunoassay in the rat CL in the different groups (COh, PG4h and PG+S4h). Different letters (a, b, c) over the error bars represent significant differences $(\mathrm{p}<0.05)$ between treatments $(\mathrm{n}=3-4$ per group $)$. 